\title{
Psychological Distress, Substance Use, and Adjustment among Parents Living with HIV
}

\author{
Risë B. Goldstein, PhD, MPH, Mallory O. Johnson, PhD, \\ Mary Jane Rotheram-Borus, PhD, Sheri B. Kirshenbaum, PhD, \\ Rogério M. Pinto, PhD, LMSW, Lauren Kittel, PsyD, Willo Pequegnat, PhD, \\ Joanne D. Mickalian, MA, Lance S. Weinhardt, PhD, Jeffrey A. Kelly, PhD, \\ Marguerita Lightfoot, PhD, and the National Institute Mental Health Healthy Living \\ Project Team
}

Background: Being a parent, especially a custodial parent, living with HIV was anticipated to increase psychological distress and challenges to self-care.

Methods: Mental health symptoms, substance use, and health care utilization were assessed among 3818 HIV-infected adults, including custodial parents, noncustodial parents, and nonparents, in 4 AIDS epicenters.

Results: Custodial parents demonstrated significantly poorer medication adherence and attendance at medical appointments but were similar to nonparents and noncustodial parents in mental health symptoms and treatment utilization for mental health and substance use problems. Noncustodial parents demonstrated the highest levels of recent substance use and substance abuse treatment. Other markers of risk, such as African American ethnicity, lack of current employment income, and injection drug use moderated many of the apparent psychosocial disadvantages exhibited by parents.

Conclusions: Interventions specific to the psychosocial stressors facing families living with HIV are needed. (J Am Board Fam Pract 2005;18:362-73.)

Parents comprise $\sim 20 \%$ of HIV-positive $(\mathrm{HIV}+)$ persons in the United States and are increasing in numbers ${ }^{1}$ as advances in medical care enable HIV+ women and men to live longer, healthier lives, ${ }^{1}$ and undertake pregnancies with low risk of vertical HIV transmission to their offspring. ${ }^{2}$

Submitted, revised, 4 May 2005.

From the Center for Community Health, UCLA Neuropsychiatric Institute (RBG, MJR-B, ML); Center for AIDS Prevention Studies, University of California-San Francisco, San Francisco, CA (MOJ, JDM); HIV Center for Clinical and Behavioral Studies, New York State Psychiatric Institute and Columbia University, New York, NY (SBK, RMP, LK); National Institute of Mental Health, Bethesda, MD (WP); Center for AIDS Intervention Research, Medical College of Wisconsin, Milwaukee, WI (LSW, JAK).

Funding: This research was funded by National Institute of Mental Health Grants U10-MH57636, U10-MH57631, U10-MH57616, and U10-MH57615 and NIMH center Grants P30-MH058107 (to MJR-B), P30-MH57226 (to JAK), P30-MH43520 (to Anke A. Ehrhardt, PhD), and P30MH062246 (to Thomas J. Coates, PhD).

Conflict of interest: none declared.

Corresponding author: Risë B. Goldstein, $\mathrm{PhD}, \mathrm{MPH}, \mathrm{Lab}-$ oratory of Epidemiology and Biometry, Division of Intramural Clinical and Biological Research, National Institute on Alcohol Abuse and Alcoholism, National Institutes of Health, 5635 Fishers Lane, Room 3068, MS 9304, Bethesda, MD 20892-9304 (e-mail goldster@mail.nih.gov).
Psychological distress and substance abuse are common among HIV+ adults. Over a third of $\mathrm{HIV}+$ adults in medical care screen positive for a psychiatric disorder. ${ }^{3}$ Symptoms of depression and anxiety have been reported in several studies of $\mathrm{HIV}+$ persons. $^{4-6}$ Similar to samples of adults without HIV, significantly more HIV + women than men are emotionally distressed. ${ }^{7,8}$ In addition, $12 \%$ of adults living with HIV were dependent on illicit drugs during the preceding year. ${ }^{3}$ However, limited data are available about how parental roles are associated with mental health among HIV+ parents.

\section{Role Theory, Mental Health, and Adjustment in HIV+ Parents}

Role theory concerns behaviors that characterize persons within contexts and with the processes that may produce, explain, or be affected by those behaviors. " The role of "parent" carries extensive expectations for behavior: providing for families' basic survival needs such as housing, food, and health care; psychologically nurturing and disciplining children; and educating children to become productive, contributing citizens. ${ }^{10}$ However, 
within this general framework, there are very different expectations for custodial versus noncustodial parents, and mothers versus fathers, some reflecting externally imposed norms and others reflecting parents' own beliefs about parenting. ${ }^{11-13}$

\section{Role Negotiation, Role Overload, and Role Conflict}

Rather than merely signifying understanding and compliance on the part of the person holding a role (the "focal person"), role development is characterized by interactive negotiation toward mutually satisfactory role definition between the focal person and others whose expectations define and shape the role, known as the "role set."14-17 However, for $\mathrm{HIV}+$ parents, many of whom are ethnic minority women heading households of low socioeconomic status, options for satisfactory role negotiation may be constrained by poverty, lack of social support, and multiple competing obligations.

More than many other parents, ${ }^{18,19}$ those with HIV, particularly custodial parents, may become overwhelmed by the simultaneous demands of multiple roles, including medical patient, breadwinner, and caregiver for $\mathrm{HIV}+$ family members. ${ }^{20-27}$ $\mathrm{HIV}+$ parents may thus experience role overload as divergent demands are superimposed on each other and cannot be easily accomplished given available time and resources. ${ }^{12}$ Parents with HIV, especially custodial mothers, may also be particularly vulnerable to role conflict; for example, their obligations to attend to their children, earn a living, and care for other family members, may render them unable to meet their own health needs. ${ }^{21,28-30}$

\section{Parental Role and Mental Health of HIV+ Parents}

Both rewards and stressors related to parenthood have been well documented. Parents may benefit from the bond with the child and the opportunity to nurture the child's development, ${ }^{13,31}$ experiencing psychological growth in the process. ${ }^{32}$ However, child physical and behavioral problems, financial strains, and caregiving demands may leave little time for parental self-care. ${ }^{29,31,33-35}$ Among custodial, inner-city mothers with HIV, perceived parenting stress, more household members, and disclosure of HIV seropositivity to fewer family members predicted medication non-adherence and missed medical appointments. ${ }^{29}$ However, little is known about whether parenthood, particularly custodial parenting, is associated with differential risk for conditions like depression, anxiety, substance use and abuse, or, conversely, increased positive states of mind or coping self-efficacy, among $\mathrm{HIV}+$ adults, especially since highly active antiretroviral therapy (HAART) has become widely available.

Because mothers more often than fathers are custodial parents and primary caretakers of children, ${ }^{24,36-40}$ most studies of mental health in HIV + parents have focused on mothers. However, fathers ${ }^{1,38}$ and noncustodial parents may also be actively involved in parenting. To our knowledge, no study has yet examined whether associations between parenthood and mental health vary by custodial role, gender, sexual orientation, or behavioral risk.

The present study examines mental health, substance use, coping self-efficacy, positive states of mind, and physical and mental health service utilization, among a large, diverse, HAART era sample of HIV+ custodial parents, noncustodial parents, and nonparents. Grounded in the concepts of role theory, we hypothesized the following:

1. Custodial parents would demonstrate the greatest distress including depression, anxiety, perceived stress, and anger burnout, as well as the lowest coping self-efficacy and mental health and substance abuse treatment utilization.

2. Custodial parents would demonstrate poorer medication adherence and attendance at scheduled medical appointments than noncustodial parents and nonparents.

3. Larger numbers of total and coresident minor offspring would be associated with greater distress and less service utilization.

4. Noncustodial parents would demonstrate distress, coping self-efficacy, and service utilization intermediate between those of custodial parents and those of nonparents.

5. Associations of parental status with distress and adjustment would be moderated by behavioral risk group and ethnicity, with women and ethnic minority group members scoring highest on distress and lowest on coping self-efficacy and treatment utilization.

6. Associations of parental status with distress and adjustment would also be moderated by current employment and welfare income, with parents reporting current employment income 
being less and those reporting current welfare income being more distressed.

\section{Methods}

\section{Study Participants}

A total of 3818 HIV+ adults in San Francisco, Los Angeles, New York City, and Milwaukee were screened for recruitment into a clinical trial of an individually administered cognitive-behavioral intervention to enhance coping skills, decrease sexual transmission risk behaviors, and improve antiretroviral medication adherence. Participants were classified by behavioral risk group using a hierarchy similar to the one established by the Centers for Disease Control and Prevention ${ }^{41}$ : women, injection drug users (IDU), men who have sex with men (MSM), and heterosexual men. If women were IDUs, they were classified as women; if MSM were IDU, they were classed as IDU. MSM were men who reported sexual contact with other males in the past 3 months, regardless of self-identification as gay or whether they also had female partners. IDU were men who reported injecting illicit substances in the past 12 months.

Recruitment and screening were undertaken in medical clinics, community agencies, and through advertisements in newspapers and magazines. Persons learning of the study by word of mouth were also eligible for screening. Interested persons who provided verbal consent were briefly screened to determine their self-reported HIV status as well as basic demographic and contact information. If they then wished to participate, they were scheduled for a baseline interview.

Participants were required to be at least 18 years old and provide written informed consent and medical documentation of their HIV + serostatus. Potential participants were excluded if they showed severe neuropsychological impairment or psychosis as assessed on a case-by-case basis by senior project personnel in collaboration with the clinical supervisor at the involved institution.

\section{Assessment Procedures}

We report data from the baseline interview that determined eligibility for the trial. All procedures and forms were reviewed and approved by the sites' Institutional Review Boards. Interviews were conducted in private settings at research offices, community-based organizations, and clinics in the 4 cities over periods of 2 to 4 hours with regular breaks to minimize respondent fatigue. Participants were compensated $\$ 50$ for completing the baseline interview; those needing childcare could also receive $\$ 10$ to defray childcare costs.

Procedures involved a combination of audio computer-assisted self-interviewing (ACASI) and computer-assisted personal interviewing using Questionnaire Development System version 2.0 by Nova Research Company. ACASI has been proposed as an effective method of decreasing social desirability and thereby enhancing veracity of selfreport of sensitive behaviors and attitudes. ${ }^{42,43}$

Interviewers were centrally trained with the use of a detailed assessment manual, practice with the computer programs, participation in an intensive 3-day training program, and review and certification of audiotaped mock interviews based on standardized criteria. All interviews were audiotaped; quality assurance ratings indicated $\geq 90 \%$ adherence to assessment protocols.

\section{Measures \\ Demographics}

Demographic data included participant age, race/ ethnicity, gender, relationship status, education, employment, income sources, and housing arrangements.

\section{Parental Status}

Total number of offspring, number residing with participants, and how many of those residing with participants were under the age of 18 were ascertained. Participants were classified as custodial parents (offspring under age 18 residing with respondents), noncustodial parents (offspring all over age 18 or not residing with respondents), or nonparents.

\section{Health Status}

Respondents were asked how long ago they learned of their HIV infection. In addition, they were asked whether they had experienced each of 25 symptoms in the preceding 30 days based on the AIDS Clinical Trials Group symptom checklist ${ }^{44}$ and to rate how much each symptom experienced bothered them. Further, participants were asked to report their most recent CD4 and viral load counts. 


\section{Health Care Utilization}

Current utilization of antiretroviral therapy; antidepressant, antianxiety, and other psychiatric medications; and mental health and substance abuse treatment visits over the past 3 months were assessed using items adapted from the Health Outcomes Study. ${ }^{45}$ In addition, respondents were asked about missed appointments with care providers.

Medication adherence was assessed with a survey developed for use in AIDS clinical trials. ${ }^{46}$ The measure allowed respondents to indicate how many prescribed antiretroviral pills they had missed taking during each of the previous 3 days. Respondents were classified as adherent if they reported no missed doses, and non-adherent if they reported any, during the 3 days.

\section{Mental Health, Psychosocial Adjustment, and Substance Use}

Response variables for the present report consisted of: depression, anxiety, anger burnout, "frequent" substance use (defined below), perceived stress, and positive states of mind.

Depression was assessed using the 21-item Beck Depression Inventory (BDI), ${ }^{47,48}$ with score cutpoints for defining moderate (14 to 20 ) and severe ( $\geq 21)$, versus none or minimal (0 to 4 ) and mild (5 to 13) depression as recommended by Shaver and Brennan. ${ }^{49}$ This measure assesses the severity of depression during the past week.

Anxiety was assessed with the State Form of the State-Trait Anxiety Inventory (STAI). ${ }^{50}$ The State Form assesses feelings of anxiety at the time the subject completes the scale. This measure was modeled both as a continuous variable and as $>$ versus $<=$ the median score for general medical patients ${ }^{50}$ of 42 .

Anger burnout was assessed with a 16-item scale adapted from the Anger and Fatigue subscales of the Profile of Mood States. ${ }^{51}$ An overall burnout score was created by summing the ratings using a 5 -point Likert-type response format and a dichotomous variable was created denoting scores $>2$.

Substance use frequency in the past 3 months was assessed for alcohol, cocaine/crack, sedatives, tranquilizers, stimulants, analgesics, inhalants, marijuana, hallucinogens, heroin, and other, participant-specified substances. Participants were asked to report which drugs they injected, their frequency of injection, and the ways they obtained injection equipment. ${ }^{52}$ Participants were classified as having "frequent" substance use if they reported consuming alcohol more than daily, any other drug 4 or more times weekly, or any IDU in the past 3 months.

Perceived stress was assessed with the 10-item form of the Perceived Stress Scale ${ }^{53}$ by summing ratings on a 5 -point scale. The questions in the scale ascertain the frequency with which subjects have experienced stress-related thoughts and feelings during the past month.

The Positive States of Mind Scale assesses satisfying states a person may have experienced in the past week. ${ }^{54}$ This self-report 6-item measure assesses: focused attention, productivity, responsible care-taking, restful repose, sensuous nonsexual pleasure, and sharing. A general composition of positive states of mind was obtained by summing across each domain on a 4-point Likert-type scale.

Coping self-efficacy was assessed with an abbreviated 15 -item version of the 26-item scale developed for a coping skills training study ${ }^{55}$ in collaboration with Dr. Albert Bandura of Stanford University. Participants rate on a scale from 0 to 10 the extent to which they believe they can perform behaviors important to adaptive coping.

\section{Statistical Analyses}

Bivariate associations of categorical response variables with parental status were analyzed using contingency table approaches and $\chi^{2}$ statistics; those between continuous response variables and parental status were analyzed using normal-theory analyses of variance and post hoc Scheffé comparisons. Among custodial parents, associations between number of coresident minor children and response variables were examined using nonparametric Spearman rank-order correlation coefficients for continuous and Wilcoxon rank-sum tests for categorical responses.

Multivariable regression models were fit to control for potentially confounding effects of respondent demographic and clinical characteristics on associations between parental status and response variables. Normal-theory regression was used for continuous responses, and binary logistic regression was used for dichotomous responses. ${ }^{56}$ Parental status was modeled using 2 indicator variables, one denoting custodial and one denoting noncustodial parents, with nonparents as the referent group. Other covariates were included based on 
associations in bivariate analyses with parental status at $P<.10$ or subject matter considerations: (a) age; (b) behavioral risk group; (c) study site; (d) education; (e) primary relationship (none, noncohabiting, cohabiting); (f) employment income; (g) welfare income; (h) use of antiretroviral medications; and (i) distress because of HIV symptoms.

Odds ratios were considered statistically significant when the surrounding 95\% CI excluded 1.00; normal-theory regression coefficients were considered statistically significant when the surrounding 95\% CI excluded 0.00. Two-way interactions of parental status with behavioral risk group, ethnicity, employment income, welfare income, distress because of HIV symptoms, and age were tested for statistical significance, with an $\alpha$-to-stay of 0.05 . All analyses were performed with SAS Statistical Software, version $8.2 .^{57}$

\section{Results}

\section{Sample Demographics}

Demographic characteristics are shown by parental status in Table 1. Custodial parents comprised $10.5 \%$, noncustodial parents $34.6 \%$, and nonparents $54.9 \%$ of the sample. Women were over-represented among custodial parents (72.6\%), whereas nonparents were predominantly MSM (69.7\%). Custodial parents were significantly younger than nonparents and noncustodial parents; nonparents were significantly younger than noncustodial parents (data available on request). Respondents differed significantly by parental status on ascertainment site, with nonparents disproportionately ascertained in Los Angeles (36.9\%) and San Francisco $(29.4 \%)$, and noncustodial parents in New York (47.7\%; $P<.0001)$. Differences by parental status on most other demographic characteristics parallel geographic differences in the epidemiology and demography of HIV. ${ }^{58}$

Custodial parents were most likely to be cohabiting with a primary partner, whereas nonparents and noncustodial parents modally reported no primary relationship. Custodial parents had a mean \pm $\mathrm{SD}$ of $1.7 \pm 1.0$ coresident minor children (women: mean $\pm \mathrm{SD}, 1.8 \pm 1.0 ; \mathrm{MSM}$ : mean $\pm \mathrm{SD}, 1.1 \pm$ 0.3 ; heterosexual men: mean $\pm \mathrm{SD}, 1.5 \pm 0.9$; women had significantly more than MSM, $P<.05$, by Scheffé's test).

\section{HIV-Related Health Status and Medical Care \\ Adberence}

HIV-related health indices are shown in Table 2. Consistent with the more recent spread of the US epidemic among women and heterosexual men than among MSM, both groups of parents had learned their serostatus more recently than nonpar-

Table 1. Sociodemographic Characteristics of Adults Living with HIV by Parental Status ( $=3810$ )*

\begin{tabular}{|c|c|c|c|c|c|}
\hline Characteristic & $\begin{array}{l}\text { Total } \\
\text { Sample } \\
(\%)\end{array}$ & $\begin{array}{l}\text { Custodial Parents } \\
\text { of Minor Children } \\
(\mathrm{n}=401)(\%)\end{array}$ & $\begin{array}{l}\text { Noncustodial/Parents } \\
\text { of Grown Children } \\
(\mathrm{n}=1319)(\%)\end{array}$ & $\begin{array}{l}\text { Nonparents } \\
(\mathrm{n}=2090) \\
(\%)\end{array}$ & $P$ Value \\
\hline Age in years, mean \pm SD & $41.5 \pm 7.6$ & $38.9 \pm 6.2$ & $43.4 \pm 7.4$ & $40.7 \pm 7.7$ & $<.0001$ \\
\hline $\begin{array}{l}\text { Behavioral risk group } \\
\text { MSM } \\
\text { IDU } \\
\text { Women } \\
\text { Heterosexual men }\end{array}$ & $\begin{array}{r}45.6 \\
8.1 \\
27.1 \\
19.2\end{array}$ & $\begin{array}{r}6.7 \\
1.8 \\
72.6 \\
19.0\end{array}$ & $\begin{array}{r}19.3 \\
6.4 \\
41.3 \\
33.0\end{array}$ & $\begin{array}{r}69.7 \\
10.3 \\
9.4 \\
10.6\end{array}$ & $<.0001$ \\
\hline $\begin{array}{l}\text { Ethnicity } \\
\text { African American } \\
\text { Hispanic } \\
\text { White } \\
\text { Other }\end{array}$ & $\begin{array}{r}48.3 \\
19.1 \\
25.7 \\
7.0\end{array}$ & $\begin{array}{r}59.6 \\
25.9 \\
10.2 \\
4.2\end{array}$ & $\begin{array}{r}62.8 \\
17.2 \\
13.9 \\
6.2\end{array}$ & $\begin{array}{r}36.9 \\
19.0 \\
36.1 \\
8.0\end{array}$ & $<.0001$ \\
\hline Currently in a cohabiting primary relationship & 23.5 & 40.4 & 24.9 & 19.3 & $<.0001$ \\
\hline Educational attainment $<$ high school graduation & 26.2 & 40.5 & 34.5 & 18.2 & $<.0001$ \\
\hline Currently residing in own house or apartment & 62.8 & 77.0 & 57.8 & 63.2 & $<.0001$ \\
\hline $\begin{array}{l}\text { Current employment status } \\
\text { Legal job, paying income taxes } \\
\text { Legal job, paid "under the table" } \\
\text { Illegal job }\end{array}$ & $\begin{array}{r}15.6 \\
13.6 \\
0.9\end{array}$ & $\begin{array}{r}15.5 \\
13.0 \\
1.3\end{array}$ & $\begin{array}{r}10.8 \\
12.3 \\
1.0\end{array}$ & $\begin{array}{r}18.7 \\
15.6 \\
0.8\end{array}$ & $<.0001$ \\
\hline Receives public assistance & 32.5 & 54.1 & 36.9 & 25.5 & $<.0001$ \\
\hline
\end{tabular}

* Information on parental status is missing for 8 participants. 


\begin{tabular}{|c|c|c|c|c|c|}
\hline Characteristic & $\begin{array}{l}\text { Total } \\
\text { Sample }\end{array}$ & $\begin{array}{l}\text { Custodial Parents } \\
\text { of Minor Children } \\
\text { (n=401) }\end{array}$ & $\begin{array}{l}\text { Noncustodial/Parents } \\
\text { of Grown Children } \\
\qquad(\mathrm{n}=1319)\end{array}$ & $\begin{array}{l}\text { Nonparents } \\
(\mathrm{n}=2090)\end{array}$ & $P$ Value \\
\hline $\begin{array}{l}\text { Years since learned HIV serostatus, } \\
\text { mean } \pm \mathrm{SD}\end{array}$ & $8.4 \pm 4.7$ & $7.7 \pm 4.1$ & $8.1 \pm 4.5$ & $8.8 \pm 4.8$ & $<.0001$ \\
\hline Last self-reported CD4 count $<200$ & $20.4 \%$ & $15.1 \%$ & $20.7 \%$ & $21.2 \%$ & .0309 \\
\hline Last viral load detectable (self-report) & $59.3 \%$ & $54.7 \%$ & $58.1 \%$ & $61.0 \%$ & .0377 \\
\hline $\mathrm{HIV}$-related symptom count, mean $\pm \mathrm{SD}$ & $12.4 \pm 5.7$ & $12.4 \pm 5.9$ & $12.3 \pm 5.9$ & $12.6 \pm 5.5$ & .3145 \\
\hline $\begin{array}{l}\text { Distress due to HIV-related symptoms, } \\
\text { mean } \pm \mathrm{SD} \dagger\end{array}$ & $2.8 \pm 0.5$ & $2.9 \pm 0.5$ & $2.9 \pm 0.5$ & $2.8 \pm 0.5$ & $<.0001$ \\
\hline Currently taking antiretrovirals & $74.7 \%$ & $72.6 \%$ & $73.7 \%$ & $75.7 \%$ & .2378 \\
\hline Adherent to all medications, past 3 days & $63.7 \%$ & $53.0 \%$ & $63.5 \%$ & $65.8 \%$ & .0002 \\
\hline $\begin{array}{l}\text { Any missed medical appointments, } \\
\text { past } 3 \text { months }\end{array}$ & $47.7 \%$ & $53.0 \%$ & $48.9 \%$ & $46.1 \%$ & .0418 \\
\hline
\end{tabular}

* Information on parental status is missing for 8 participants.

† Rated 1 (doesn't bother at all) to 4 (bothers a great deal).

ents. The groups did not differ significantly on $\mathrm{HIV}$-related symptom counts (mean $\pm \mathrm{SD}$, custodial parents: $12.4 \pm 5.9$; noncustodial parents: $12.3 \pm 5.9$; nonparents: $12.6 \pm 5.5$ ). However, although differences were modest, both groups of parents reported greater distress than nonparents because of HIV symptoms.

Custodial parents were significantly less likely than noncustodial parents and nonparents to report that their last CD4 count was $<200$ or that their viral load was detectable. However, custodial parents were also significantly less likely to report $100 \%$ antiretroviral medication adherence over the past 3 days (adjusted odds ratio 0.60, 95\% CI, 0.44, 0.82 ) and more likely to report missing medical appointments over the preceding 3 months.

\section{Mental Health and Psychosocial Adjustment}

Relationships between mental health and parental status are shown in Table 3. Although the difference was modest, custodial parents scored significantly lower than nonparents on positive states of mind. However, neither significant main effects of parental status nor significant interactions of parental status with other demographic or clinical variables were observed for anger burnout $32.8 \%$ of the total sample scoring $>2)$, moderate/severe depression $(39.9 \%)$, antidepressant $(30.8 \%)$ or other psychiatric medication use (11.7\%), mental health visits in the past 3 months $(39.2 \%)$, or perceived stress (mean $\pm \mathrm{SD}, 18.8 \pm 7.0)$.

\section{Interactions of Parental Status with Demographic} Characteristics

Significant interactions of parental status with ethnicity, behavioral risk group, and income sources were observed on the BDI, STAI, substance use, substance abuse treatment, and coping self-efficacy.

On the BDI, custodial IDU fathers were significantly more depressed than nonparental MSM. Custodial mothers were less likely to utilize substance abuse services, whereas noncustodial MSM and IDU fathers were more likely.

African American and Hispanic custodial parents displayed significantly decreased odds of frequent substance use, whereas white noncustodial parents demonstrated significantly increased odds, compared with African American nonparents.

Coping self-efficacy was significantly lower among African American MSM and IDU fathers, particularly those with custody, than among African American MSM nonparents. It was also significantly lower among noncustodial MSM and IDU fathers of "other ethnicities," but higher among both noncustodial and custodial Hispanic and noncustodial white mothers. In other behavioral risk and ethnic groups, the estimated regression coefficients $(95 \% \mathrm{CI})$ were statistically nonsignificant, ranging from $-1.47(-3.10,0.16)$ for custodial IDU fathers of other ethnicities to $0.47(0.00,0.93)$ for noncustodial Hispanic heterosexual men.

Anxiety was significantly higher among both groups of African American parents who did not, and among noncustodial African American parents who did, have employment income, than 
Table 3. Crude and Adjusted Associations of Mental Health and Adjustment Measures with Parental Status $(\mathrm{N}=$ 3810)*

\begin{tabular}{|c|c|c|c|c|c|c|}
\hline \multirow[b]{2}{*}{ Measure } & \multirow[b]{2}{*}{$\begin{array}{l}\text { Total } \\
\text { Sample }\end{array}$} & \multirow{2}{*}{$\begin{array}{l}\text { Custodial } \\
\text { Parents } \\
\text { of Minor } \\
\text { Children } \\
(\mathrm{n}=401)\end{array}$} & \multirow{2}{*}{$\begin{array}{c}\text { Noncustodial/ } \\
\text { Parents } \\
\text { of Grown } \\
\text { Children } \\
(\mathrm{n}=1319)\end{array}$} & \multirow[b]{2}{*}{$\begin{array}{l}\text { Nonparents } \\
(\mathrm{n}=2090)\end{array}$} & \multicolumn{2}{|c|}{$\begin{array}{c}\text { Adjusted Odds Ratios } \\
\text { or Regression } \\
\text { Coefficients }(95 \% \text { CI) } \dagger\end{array}$} \\
\hline & & & & & $\begin{array}{l}\text { Custodial vs. } \\
\text { nonparents }\end{array}$ & $\begin{array}{l}\text { Noncustodial vs. } \\
\text { nonparents }\end{array}$ \\
\hline $\begin{array}{l}\text { Beck Depression } \\
\text { Inventory score, } \\
\text { mean } \pm \mathrm{SD}\end{array}$ & $12.9 \pm 9.0$ & $13.1 \pm 9.3$ & $13.0 \pm 9.1$ & $12.8 \pm 8.8$ & & \\
\hline MSM & & & & & $0.88(-2.15,3.90)$ & $0.60(-0.48,1.69)$ \\
\hline IDU & & & & & $13.10(6.64,19.57)$ & $1.43(-0.58,3.44)$ \\
\hline Women & & & & & $-0.66(-2.12,0.80)$ & $-0.75(-2.03,0.52)$ \\
\hline Heterosexual men & & & & & $0.33(-1.76,2.42)$ & $1.12(-0.19,2.43)$ \\
\hline $\begin{array}{l}\text { Frequent } † \text { substance use } \\
(\%)\end{array}$ & 31.6 & 22.7 & 33.2 & 32.4 & & \\
\hline African American & & & & & $0.63(0.43,0.92)$ & $0.87(0.68,1.13)$ \\
\hline Hispanic & & & & & $0.46(0.21,0.98)$ & $1.40(0.94,2.09)$ \\
\hline White & & & & & $0.84(0.51,2.72)$ & $1.52(1.03,2.25)$ \\
\hline Other ethnicities & & & & & $0.87(0.65,1.16)$ & $1.06(0.58,1.94)$ \\
\hline $\begin{array}{l}\text { Substance abuse } \\
\text { treatment, past } 3 \\
\text { months (\%) }\end{array}$ & 46.1 & 41.7 & 59.1 & 38.7 & & \\
\hline MSM & & & & & $1.06(0.46,2.43)$ & $1.51(1.14,2.01)$ \\
\hline IDU & & & & & $3.52(0.39,31.62)$ & $2.49(1.35,4.59)$ \\
\hline Women & & & & & $0.47(0.32,0.69)$ & $1.24(0.88,1.75)$ \\
\hline Heterosexual men & & & & & $0.93(0.54,1.61)$ & $1.36(0.64,1.26)$ \\
\hline $\begin{array}{l}\text { STAI score, mean } \pm \mathrm{SD} \\
\text { African American, no } \\
\text { current employment } \\
\text { income }\end{array}$ & $36.3 \pm 11.0$ & $37.2 \pm 11.4$ & $36.0 \pm 10.7$ & $36.3 \pm 11.1$ & $4.40(2.60,6.20)$ & $2.19(1.00,3.38)$ \\
\hline $\begin{array}{l}\text { African American, } \\
\text { current employment } \\
\text { income }\end{array}$ & & & & & $1.34(-1.04,3.72)$ & $1.68(0.62,3.99)$ \\
\hline STAI score >42 (\%) & 26.5 & 29.8 & 25.8 & 26.3 & & \\
\hline African American & & & & & $2.20(1.51,3.22)$ & $1.60(1.21,2.10)$ \\
\hline Hispanic & & & & & $0.46(0.21,0.98)$ & $1.40(0.94,2.09)$ \\
\hline White & & & & & $0.84(0.51,2.72)$ & $1.52(1.03,2.25)$ \\
\hline Other ethnicities & & & & & $0.49(0.15,1.62)$ & $1.06(0.58,1.94)$ \\
\hline $\begin{array}{l}\text { Currently taking anti- } \\
\text { anxiety medication } \\
\text { (\%) }\end{array}$ & 19.7 & 19.2 & 17.1 & 21.5 & & \\
\hline $\begin{array}{l}\text { No current welfare } \\
\text { income }\end{array}$ & & & & & $0.85(0.53,1.35)$ & $0.99(0.77,1.28)$ \\
\hline $\begin{array}{l}\text { Current welfare } \\
\text { income }\end{array}$ & & & & & $1.79(1.10,2.92)$ & $1.01(0.70,1.46)$ \\
\hline $\begin{array}{l}\text { Positive States of Mind } \\
\text { Scale, mean } \pm \text { SD }\end{array}$ & $12.9 \pm 3.5$ & $12.9 \pm 3.6$ & $13.0 \pm 3.6$ & $12.9 \pm 3.4$ & $-0.48(-0.89,-0.07)$ & $-0.24(-0.51,0.03)$ \\
\hline $\begin{array}{c}\text { Coping self-efficacy, } \\
\text { mean } \pm \text { SD }\end{array}$ & $6.6 \pm 1.8$ & $6.7 \pm 1.8$ & $6.7 \pm 1.8$ & $6.6 \pm 1.8$ & & \\
\hline $\begin{array}{l}\text { African American, } \\
\text { MSM }\end{array}$ & & & & & $-0.94(-1.59,-0.28)$ & $-0.56(-0.82,-0.30)$ \\
\hline $\begin{array}{l}\text { African American, } \\
\text { IDU }\end{array}$ & & & & & $-1.40(-2.80,0.00)$ & $-0.85(-1.32,-0.38$ \\
\hline Hispanic, women & & & & & $0.46(0.01,0.91)$ & $0.55(0.18,0.92)$ \\
\hline White, women & & & & & $0.37(-0.22,0.93)$ & $0.51(0.13,0.89)$ \\
\hline $\begin{array}{l}\text { Other ethnicities, } \\
\text { MSM }\end{array}$ & & & & & $-1.00(-2.04,0.03)$ & $-0.57(-1.05,-0.10)$ \\
\hline Other ethnicities, IDU & & & & & $-1.47(-3.10,0.16)$ & $-0.86(-1.46,-0.27)$ \\
\hline
\end{tabular}

* Information on parental status is missing for 8 participants.

$\dagger$ Defined as alcohol $>$ daily, any other drug $\geq 4$ times weekly, or any injection in the past 3 months.

among African American nonparents. For other subgroups defined by ethnicity and income, the estimated regression coefficients (95\% CI) were statistically nonsignificant, ranging from -2.20 $(-5.91,1.50)$ for white custodial parents with, to $3.95(-1.30,9.21)$ for custodial parents of 
other ethnicities without, current employment income.

\section{Associations with Primary Relationship Status}

Primary relationship did not interact with parental status in association with mental health variables. However, being in a primary relationship was independently associated with lower BDI and STAI and higher Positive States of Mind Scale scores, particularly among respondents who cohabited with their primary partners. Primary, cohabiting relationships were also associated with lower utilization of antidepressants, other psychiatric medications, substance abuse treatment, and mental health visits, but higher odds of frequent substance use. Primary, noncohabiting relationships were associated with higher odds of substance abuse treatment and higher coping self-efficacy.

\section{Associations between Number of Offspring and Response Variables}

Not shown here but available on request, Spearman rank-order correlations between total number of offspring and continuous response variables did not differ from zero. In the sample as a whole, current antianxiety medication was associated with fewer (Wilcoxon rank sum $\chi^{2}=10.95, d f=1, P=.0009$ ), and substance abuse treatment with more offspring (Wilcoxon rank sum $\chi^{2}=107.85, d f=1, P<$ .0001). Among custodial parents, frequent substance use was associated with fewer (Wilcoxon rank sum $\left.\chi^{2}=4.51, d f=1, P=.0336\right)$, and substance abuse treatment (Wilcoxon rank sum $\chi^{2}$ $=3.93, d f=1, P=.0475)$ and current antidepressant medication (Wilcoxon rank sum $\chi^{2}=5.70$, $d f=1, P=.0170$ ) with more offspring. Number of minor offspring residing with custodial parents was not significantly associated with any response variables.

\section{Discussion}

To our knowledge, this study is among the first to examine mental health, psychosocial adjustment, and substance use among a large, diverse, HAART era sample of HIV+ custodial parents, noncustodial parents, and nonparents. Parenthood is associated with substantial role responsibilities and potential stressors. Unexpectedly, however, there were few differences by parental status in mental health, substance abuse, or treatment utilization.
Most associations that we observed identified parents, especially custodial ones, as more distressed than nonparents, and indicated that custodial parents had particular difficulty with medication adherence and attendance at medical appointments. However, these differences were relatively modest.

In the case of substance abuse, caring for young children may be protective, because substance abuse is more prevalent among noncustodial than custodial parents. This may reflect the increased propensity for parents with serious substance use problems to lose or relinquish custody and perhaps to seek treatment as part of the process of getting the children back. Similarly, custody of children may be an incentive for parents to abstain from substances. ${ }^{59}$

Consistent with previous studies of risk factors for psychological distress, many of the disadvantages exhibited by parents were moderated by other variables that are often markers of socioeconomic disadvantage, such as African American ethnicity, lack of current employment income, and injection of drugs over the preceding 12 months. ${ }^{60}$ Being in a primary relationship did not moderate associations with parental status, either to reduce distress or to increase positive adjustment. In addition, neither total number of offspring nor number of minor children living in the home was associated with most psychological measures.

African American and Hispanic custodial parents were less likely to report frequent substance use; both custodial and noncustodial Hispanic mothers, as well as white noncustodial mothers, endorsed greater coping self-efficacy, whereas African American MSM and African American IDU fathers, and IDU fathers of ethnicities other than African American, Hispanic, and white, reported less. The lower odds we observed for frequent substance use among custodial African American and Hispanic parents are compatible with previous epidemiologic studies that identify lower prevalence in ethnic minority groups. ${ }^{61-63}$ However, the higher scores of Hispanic mothers on coping selfefficacy have not, to our knowledge, been reported previously. The high valuation of family roles and the strong and supportive extended family networks that are prevalent in many Hispanic subcultures may have salutary effects on the mental health of mothers, perhaps discouraging problematic substance use and increasing the confidence of women in their ability to cope even with multiple stressors 
and challenges posed by poverty and by living and parenting with HIV.

Our findings provide limited support for assertions that parenthood, particularly the custodial role, is associated with increased psychological distress. Furthermore, the lower levels of distress associated with cohabiting primary relationships and paid work, as well as the lack of correlations between total number of offspring and measures of distress, argue against contributions to psychological distress by role overload and role conflict in this sample. The potentially supportive role of a cohabiting primary partner and paid work may act as buffers against stresses resulting from other sources of role overload or conflict. However, we advance these assertions cautiously because we did not characterize the life roles of participants, expectations for themselves or the expectations of others, nor their performance in those roles, including caregiving for ill relatives.

Consistent with findings reported by Mellins et $\mathrm{al}^{29}$ we observed significantly poorer medication adherence and attendance at medical visits by custodial parents. Nevertheless, it seems less plausible to posit these as consequences than as contributors to mental health status. We also did not assess specific stressors, including poverty, nor challenges specific to parenting such as family members' knowledge of parents' HIV diagnoses. Furthermore, we did not ask respondents to identify sources of social support that could buffer those stressors.

The study is further limited by the way we assessed parental status. We did not ask about minor children not residing with participants, nor did we ascertain why noncustodial respondents did not have custody. Thus, the noncustodial parent group is probably heterogeneous, including some with adult offspring who live on their own, and others with minor children of whom they either never had or voluntarily or involuntarily relinquished custody. However, the proportions of these subgroups in our sample and their profiles on our response variables cannot be determined from our data.

Other limitations include the relatively small numbers of fathers, particularly MSM, which may have constrained our statistical power to detect parental status by behavioral risk group interactions. In addition, because our data are cross-sectional, we cannot examine changes in response variables associated with shifts in parenting responsibilities (eg, new children, or the developmental progression of young children to greater independence). Our assessment of psychiatric symptomatology did not include psychosis, antisocial behavior, cognitive impairment, or DSM-IV diagnoses. Therefore, our estimates of participants' symptomatology are probably conservative.

\section{Implications}

Despite these limitations, our findings are consistent with previous work ${ }^{3,37,64-66}$ indicating that custodial parents, noncustodial parents, and nonparents with HIV manifest psychological distress that may warrant clinical attention. For these reasons, recommendations have emerged for the integration of mental health into primary HIV care. ${ }^{3,11,67}$ Associations of behavioral health problems with both greater HIV-related morbidity ${ }^{68-71}$ and adverse outcomes in offspring ${ }^{72-74}$ indicate that clinical services for $\mathrm{HIV}+$ parents need to include careful attention to mental health concerns as they affect parents and the rest of the family. In addition, our findings concerning increased nonadherence to HAART medications and non-attendance at care appointments by custodial parents indicate that providers should pay particularly careful attention to monitoring and supporting medication adherence and attendance at follow-up visits among this subset of patients.

Future investigations should characterize the interplay between parental status and psychological distress among HIV+ adults, examine aspects of parental roles that may act as risk and protective factors for mental health and substance abuse problems, and develop interventions that will decrease identified sources of distress.

\section{The NIMH Healthy Living Trial Group Research Steering Committee (site principal investigators and NIMH staff collaborator)}

Margaret A. Chesney, PhD, ${ }^{1}$ Anke A. Ehrhardt, $\mathrm{PhD}^{2}$ Jeffrey A. Kelly, $\mathrm{PhD},{ }^{3}$ Willo Pequegnat, $\mathrm{PhD},{ }^{4}$ Mary Jane Rotheram-Borus, $\mathrm{PhD}^{5}$

\section{Collaborating Scientists, Co-Principal Investigators, and Investigators}

Eric G. Benotsch, PhD, ${ }^{3}$ Michael J. Brondino, $\mathrm{PhD},{ }^{3}$ Sheryl L. Catz, PhD, ${ }^{3}$ Edwin D. Charlebois, $\mathrm{PhD}, \mathrm{MPH},{ }^{1}$ Don C. DesJarlais, $\mathrm{PhD},{ }^{6}$ Naihua Duan, $\mathrm{PhD},{ }^{5}$ Theresa M. Exner, PhD, ${ }^{2}$ Risë B. 
Goldstein, $\mathrm{PhD}, \mathrm{MPH},{ }^{5}$ Cheryl Gore-Felton, $\mathrm{PhD},{ }^{3}$ A. Elizabeth Hirky, PhD ${ }^{2}$ Mallory O. Johnson, $\mathrm{PhD},{ }^{1}$ Robert M. Kertzner, $\mathrm{MD},{ }^{2}$ Sheri B. Kirshenbaum, $\mathrm{PhD},{ }^{2}$ Lauren E. Kittel, $\mathrm{PsyD},{ }^{2}$ Robert Klitzman, $\mathrm{MD},{ }^{2}$ Martha Lee, $\mathrm{PhD},{ }^{5}$ Bruce Levin, $\mathrm{PhD},{ }^{2}$ Marguerita Lightfoot, $\mathrm{PhD},{ }^{5}$ Stephen F. Morin, PhD,${ }^{1}$ Steven D. Pinkerton, $\mathrm{PhD},{ }^{3}$ Robert H. Remien, $\mathrm{PhD},{ }^{2}$ Fen Rhodes, $\mathrm{PhD},{ }^{5} \mathrm{Su}-$ san Tross, $\mathrm{PhD},{ }^{2}$ Lance S. Weinhardt, $\mathrm{PhD},{ }^{3}$ Robert Weiss, PhD, ${ }^{5}$ Hannah Wolfe, $\mathrm{PhD},{ }^{7}$ Rachel Wolfe, $\mathrm{PhD},{ }^{7}$ F. Lennie Wong, $\mathrm{PhD}^{5}$

\section{Data Management and Analytic Support}

Philip Batterham, MA, ${ }^{5}$ W. Scott Comulada, MS, ${ }^{5}$ Tyson Rogers, $\mathrm{MA},{ }^{5} \mathrm{Yu}$ Zhao, $\mathrm{MS}^{5}$

\section{Site Project Coordinators}

Kristin Hackl, MSW, ${ }^{3}$ Daniel Hong, MA, ${ }^{5}$ Karen Huchting, BA, ${ }^{5}$ Joanne D. Mickalian, MA, ${ }^{1}$ Margaret Peterson, $\mathrm{MSW}^{3}$

\section{NIMH}

Christopher M. Gordon, PhD, ${ }^{5}$ Dianne Rausch, $\mathrm{PhD},{ }^{5}$ Ellen Stover, $\mathrm{PhD}^{5}$

${ }^{1}$ University of California, San Francisco; ${ }^{2}$ New York State Psychiatric Institute/Columbia University, New York; ${ }^{3}$ Medical College of Wisconsin, Milwaukee; ${ }^{4}$ National Institute of Mental Health, Bethesda, Maryland; ${ }^{5}$ University of California, Los Angeles; ${ }^{6}$ Beth Israel Medical Center, New York; ${ }^{7}$ St. Luke's-Roosevelt Medical Center, New York.

We thank Ellen Stover, $\mathrm{PhD}$, and Willo Pequegnat, $\mathrm{PhD}$, at NIMH for technical assistance in developing the study and Christopher M. Gordon, $\mathrm{PhD}$, and Dianne Rausch, PhD, at NIMH for support of this research. Thanks to the Psychosexual Core of the HIV Center for Clinical and Behavioral Studies at New York State Psychiatric Institute and Columbia University, especially Heino Meyer-Bahlburg, Terry Dugan, and Theresa Exner, for collaborating with us in developing the sexual behavior interview, to the assessors in each city who conducted the interviews, to our clinic and community-based organization collaborators, to all other support staff involved in the project, and to the men and women who participated in the interviews.

\section{References}

1. Schuster MA, Kanouse E, Morton SC, et al. HIVinfected parents and their children in the United States. Am J Public Health 2000;90:1074-81.

2. Kirshenbaum SB, Hirky AE, Correale J, et al. "Throwing the dice:" pregnancy decision-making among HIV-positive women in four U.S. cities. Perspect Sex Reprod Health 2004;36:106-13.

3. Bing EG, Burnam MA, Longshore D, et al. Psychi- atric disorders and drug use among human immunodeficiency virus-infected adults in the United States. Arch Gen Psychiatry 2001;58:721-8.

4. Griffin KW, Rabkin JG. Psychological distress in people with HIV/AIDS: prevalence rates and methodological issues. AIDS Behav 1997;1:29-42.

5. Lipsitz JD, Williams JBW, Rabkin JG, et al. Psychopathology in male and female intravenous drug users with and without HIV infection. Am J Psychiatry 1994;151:1662-9.

6. Sewell MC, Goggin KJ, Rabkin JG, Ferrando SJ, McElhiney MC, Evans S. Anxiety syndromes and symptoms among men with AIDS. Psychosomatics 2000;41:294-300.

7. Semple SJ, Patterson TL, Straits-Troster K, Atkinson JH, McCutchan JA, Grant I. Social and psychological characteristics of HIV-infected women and gay men. Women Health 1996;24:17-41.

8. Rabkin JG, Johnson J, Lin SH, et al. Psychopathology in male and female HIV-positive and negative injected drug users. AIDS 1997;11:507-15.

9. Biddle BJ. Role theory: expectations, identities, and behaviors. New York: Academic Press; 1979.

10. Zayas LH, Solari F. Early childhood socialization in Hispanic families: context, culture, and practical implications. Prof Psychol: Res Pract 1994;25:200-6.

11. Fox GL, Bruce C, Combs-Orme T. Parenting expectations and concerns of fathers and mothers of newborn infants. Family Relations: Interdisciplinary Journal of Applied Family Studies 2000;49:123-131.

12. Major DA. Utilizing role theory to help employed parents cope with children's chronic illness. Health Education Research: Theory and Practice 2003;18: 45-57.

13. Parke RD. Parenting in the new millenium: prospects, promises and pitfalls. In: McHale JP, Grolnick WS, editors. Retrospect and prospect in the psychological study of families. Mahwah (NJ): Lawrence Erlbaum Associates; 2002. pp. 65-93.

14. Merton R. The role set: problems in sociological theory. Br J Sociology 1957;8:106-20.

15. Turner RH. Role-taking, role standpoint, and reference group behavior. Am J Sociology 1956;61:31628.

16. Graen G. Role making process within complex organizations. In: Dunnette MD, editor. The handbook of industrial and organizational psychology. Chicago (IL): Rand McNally; 1976. pp. 1201-45.

17. Graen G, Scandura TA. Toward a psychology of dyadic organizing. In: Cummings LL, Staw BM, editors. Research in organizational behavior. Greenwich (CT): JAI Press; 1987. pp. 175-208.

18. Verbrugge LM. Multiple roles and physical health of women and men. J Health Soc Behav 1983;24:1630.

19. Chasteen K, Kissman K. Juggling multiple roles and the act of resistance. Contemporary Family Therapy $2000 ; 22: 233-40$. 
20. Hader SL, Smith DK, Moore JS, Holberg SD. HIV infection in women in the United States. JAMA 2001;285:1186-92.

21. Crystal S, Schlosser LR. The HIV-mental health challenge. In: Horwitz AV, Scheid TL, editors. A handbook for the study of mental health: social contexts, theories, and systems. Cambridge (MA): University Press; 1999. pp. 526-49.

22. Cunningham WE, Andersen RM, Katz MH, et al. The impact of competing subsistence needs and barriers on access to medical care for persons with human immunodeficiency virus receiving care in the United States. Med Care 1999;37:1270-81.

23. Mellins CA, Ehrhardt AA. Families affected by pediatric acquired immune deficiency syndrome: sources of stress and coping. J Develop Behav Pediatrics 1994;15:54-60.

24. Mellins CA, Ehrhardt AA, Rapkin B, Havens JF. Psychosocial factors associated with adaptation in HIV-infected mothers. AIDS Behav 2000;4:317-28.

25. Mellins CA, Havens JF, McKaskill EO, Leu CS, Brudney K, Chesney MA. Mental health, substance use and disclosure are significantly associated with the medical treatment adherence of $\mathrm{HIV}$-infected mothers. Psychol Health Med 2002; 7:451-60.

26. Newshan G. Is anybody listening? A phenomenological study of pain in hospitalized persons with AIDS. J Nurses AIDS Care 1998;9:57-67.

27. Remien RH, Rabkin JG. Psychological aspects of living with $\mathrm{HIV}$ disease: a primary-care perspective. West J Med 2001;175:332-5.

28. Sha BE, Benson CA, Pottage JC, Urbanski PA, Daugherty SR, Kessler HA. HIV infection in women: an observational study of clinical characteristics, disease progression, and survival for a cohort of women in Chicago. J AIDS 1995;8:486-95.

29. Mellins CA, Kang E, Leu CS, Havens JF, Chesney MA. Longitudinal study of mental health and psychosocial predictors of medical treatment adherence in mothers living with HIV disease. AIDS Patient Care STDS 2003;17:407-16.

30. Wood SA, Tobias C, McCree J. Medication adherence for HIV positive women caring for children: in their own words. AIDS Care 2004;16:909-13.

31. Nomaguchi KM, Milkie MA. Costs and rewards of children: the effects of becoming a parent on adults' lives. J Marr Family 2003;65:356-74.

32. Cowan CP, Cowan PA. When partners become parents: the big life change for couples. New York: Basic Books; 2000.

33. Semple SJ, Patterson TL, Temoshok LR, et al. Identification of psychobiological stressors among HIVpositive women. HIV Neurobehavioral Research Center (HNRC) Group. Women Health 1993;20: 15-36.

34. Jackson AP. The effects of role strain on single, working, Black mothers' perceptions of their young children. Soc Work Research 1994;18:36-40.
35. Oyserman D, Mowbray CT, Meares PA, Firminger KB. Parenting among mothers with a serious mental illness. In: Hertzig ME, Farber EA, editors. Annual progress in child psychiatry and child development: 2000-2001. New York: Brunner-Routledge; 2003. pp. 177-216.

36. Hough ES, Brumitt G, Templin T, Saltz E, Mood D. A model of mother-child coping and adjustment to HIV. Soc Sci Med 2003;56:643-55.

37. Murphy DA, Marelich WD, Dello Stritto ME, Swendeman D, Witkin A. Mothers living with HIV/ AIDS: mental, physical, and family functioning. AIDS Care 2002;14:633-44.

38. Rotheram-Borus MJ, Lester P, Wang PW, Shen Q. Custody plans among parents living with human immunodeficiency virus infection. Arch Pediatr Adolesc Med 2004;158:327-32.

39. Silver EJ, Bauman LJ, Camacho S, Hudis J. Factors associated with psychological distress in urban mothers with late-stage HIV/AIDS. AIDS Behav 2003;7: 421-31.

40. Brook DW, Brook JS, Whiteman M, ArencibiaMireles O, Pressman MA, Rubenstone E. Coping in adolescent children of HIV-positive and HIV-negative substance-abusing fathers. J Genet Psychol 2002;163:5-23.

41. Centers for Disease Control and Prevention. Diagnoses of HIV/AIDS-32 States, 2000-2003. MMWR 2004;53:1106-10.

42. Gribble JN, Miller H, Rogers SM, Turner CF. Interview mode and measurement of sexual behaviors: methodological issues. J Sex Res 1999;36:16-24.

43. Turner CF, Ku L, Rogers SM, Lindberg LD, Pleck $\mathrm{JH}$, Sonenstein F. Adolescent sexual behavior, drug use, and violence: increased reporting with computer survey technology. Science 1998;280:867-73.

44. Justice AC, Holmes W, Gifford AL, et al. The Adult AIDS Clinical Trials Unit Outcomes Committee. Development and validation of a self-completed HIV symptom index. J Clin Epidemiol 2001;54 Suppl 1:S77-90.

45. Lubeck DP, Fries JF. Changes in health status after one year for persons at-risk for and with HIV infection. Psychol Health 1992;9:79-92.

46. Chesney MA, Ickovics JR, Chambers DB, et al. Selfreported adherence to antiretroviral medications among participants in HIV clinical trials: the AACTG adherence instruments. Patient Care Committee \& Adherence Working Group of the Outcomes Committee of the Adult AIDS Clinical Trials Group (AACTG). AIDS Care 2000;12:255-66.

47. Beck AT. Depression: causes and treatment. Philadelphia (PA): University of Pennsylvania Press; 1967.

48. Beck AT, Steer RA. Internal consistencies of the original and revised Beck Depression Inventory. J Clin Psychol 1984;40:1365-7.

49. Shaver PR, Brennan KA. Measures of depression and 
loneliness. In: Robinson JP, Shaver R, et al, editors. Measures of personality and social psychological attitudes. San Diego (CA): Academic Press, Inc.; 1991. pp. 195-289.

50. Spielberger CD, Gorsuch RL, Lushene R, Vagg PR, Jacobs GA. State-Trait Anxiety Inventory for Adults. Palo Alto (CA): Consulting Psychologists Press; 1983.

51. McNair DM, Lorr M, Droppleman LF. Profile of mood states. San Diego (CA): Educational and Industrial Testing Service; 1971.

52. Weatherby NL, Needles R, Cesari H, et al. Validity of self-reported drug use among injection drug users and crack cocaine users recruited through street outreach. Eval Prog Planning 1994;17:347-55.

53. Cohen S, Kamarck T, Mermelstein R. A global measure of perceived stress. J Health Soc Behav 1983; 24:385-96.

54. Horowitz MJ, Adler N, Kegeles S. A scale for measuring the occurrence of positive states of mind: a preliminary report. Psychosom Med 1988;50:47783.

55. Chesney MA, Chambers DB, Taylor JM, Johnson LM, Folkman S. Coping effectiveness training for men living with HIV: results from a randomized clinical trial testing a group-based intervention. Psychosom Med 2003;65:1038-46.

56. Hosmer DW, Lemeshow S. Applied logistic regression. 2nd ed. New York: John Wiley \& Sons; 2000.

57. SAS Institute, Inc. SAS Statistical Software, Version 8. Cary, NC: SAS Institute Inc.; 1999.

58. Centers for Disease Control and Prevention. HIV/AIDS surveillance report: midyear 2001 edition. MMWR CDC Surveillance Summaries 2001; 13. Available at http://www.cdc.gov/hiv/pubs/ hivprevalence/overview.htm. Accessed September 15, 2004.

59. Rittner B, Dozier CD. Effects of court-ordered substance abuse treatment in child protective services cases. Soc Work 2000;45:131-40.

60. Kessler RC, Zhao S. The prevalence of mental illness. In: Horwitz AV, Scheid TL, editors. A handbook for the study of mental health: social contexts, theories, and systems. New York: Cambridge University Press; 1999. pp. 58-78.

61. Anthony JC, Helzer JE. Syndromes of drug abuse and dependence. In: Robins LN, Regier DA, editors. Psychiatric disorders in America: the Epidemiologic Catchment Area Study. New York: The Free Press; 1991. pp. 116-154.

62. Kandel D, Chen K, Warner LA, Kessler RC, Grant B. Prevalence and demographic correlates of symptoms of last year dependence on alcohol, nicotine, marijuana and cocaine in the U.S. population. Drug Alcohol Depend 1997;44:11-29.

63. Warner LA, Kessler RC, Hughes M, Anthony JC, Nelson CB. Prevalence and correlates of drug use and dependence in the United States. Results from the National Comorbidity Survey. Arch Gen Psychiatry 1995;52:219-29.

64. Lyketsos CG, Hanson A, Fishman M, McHugh PR, Treisman GJ. Screening for psychiatric morbidity in a medical outpatient clinic for HIV infection: the need for a psychiatric presence. Int J Psychiatr Med 1994;24:103-13.

65. Pilowsky DJ, Knowlton AR, Latkin CA, Hoover DR, Chung S, Celentano DD. Children of injection drug users: impact of parental HIV status, AIDS, and depression. J Urban Health 2001;78:327-39.

66. Vitiello B, Burnam MA, Bing EG, Beckman R, Shapiro MF. Use of psychotropic medications among $\mathrm{HIV}$-infected patients in the United States. Am J Psychiatry 2003;160:547-54.

67. Dodds S, Nuehring EM, Blaney NT, et al. Integrating mental health services into primary HIV care for women: the whole life project. Public Health Rep 2004;119:48-59.

68. Sherbourne CD, Hays RD, Fleishman JA, et al. Impact of psychiatric conditions on health-related quality of life in persons with HIV infection. Am J Psychiatry 2000;157:248-54.

69. Ickovics JR, Hamburger ME, Vlahov D, et al. Mortality, CD4 cell decline, and depressive symptomatology among HIV-seropositive women: longitudinal analysis from the HIV Epidemiology Research Study. JAMA 2001;285:1466-74.

70. Jones DJ, Beach SR, Forehand R, Family Health Project Research Group. Disease status in African American single mothers with HIV: the role of depressive symptoms. Health Psychol 2001;20:417-23.

71. Patterson TL, Semple SJ, Temoshok LR, et al. Stress and depressive symptoms prospectively predict immune change among HIV-seropositive men. HIV Neurobehavioral Research Center Group. Psychiatry 1995;58:299-312.

72. Pilowsky DJ, Zybert PA, Hsieh PW, Vlahov D, Susser E. Children of HIV-positive drug-using parents. J Am Acad Child Adolesc Psychiatry 2003;42: 950-6.

73. Rotheram-Borus MJ, Stein JA. Problem behavior of adolescents whose parents are living with AIDS. Am J Orthopsychiatry 1999;69:228-39.

74. Stein JA, Riedel M, Rotheram-Borus MJ. Parentification and its impact on adolescent children of parents with AIDS. Fam Process 1999;38:193-208. 